\title{
Hedgehog Pathway Inhibitors and Their Utility in Basal Cell Carcinoma: A Comprehensive Review of Current Evidence
}

\author{
Evelyn Yu-Xin Tay · Yee-Leng Teoh • Matthew Sze-Wei Yeo
}

Received: September 24, 2018 / Published online: December 11, 2018

(c) The Author(s) 2018

\begin{abstract}
Basal cell carcinoma (BCC) is the most commonly diagnosed malignancy in humans, and as such it poses a significant healthcare burden. The majority of BCC cases are amenable to cure by surgical extirpation. However, until recently there have been no good treatment options for a significant minority of advanced BCC cases, including locally advanced BCC and metastatic BCC. The introduction of a novel class of drugs, the Hedgehog pathway inhibitors, into clinical practice has ushered in a new treatment algorithm for the treatment of difficult BCC cases. In this review we present the latest available evidence and discuss areas for further research in this rapidly evolving field.
\end{abstract}

Enhanced Digital Features To view enhanced digital features for this article go to https://doi.org/10.6084/ m9.figshare.7399232.

E. Y.-X. Tay · Y.-L. Teoh

Department of Dermatology, Changi General

Hospital, Singapore, Republic of Singapore

M. S.-W. Yeo $(\bowtie)$

Department of Plastic Surgery, Tan Tock Seng

Hospital, Singapore, Republic of Singapore

e-mail: matthew_yeo@ttsh.com.sg
Keywords: Basal cell carcinoma; Hedgehog pathway inhibitors; Skin malignancy; Sonidegib; Vismodegib

\section{INTRODUCTION}

Basal cell carcinoma (BCC) constitutes approximately $80 \%$ of non-melanoma skin cancers and is the most commonly diagnosed cancer worldwide [1]. Most BCCs are curable by surgery. Advanced BCC (locally advanced/metastatic BCC) poses a significant problem as surgery and/or radiotherapy may lead to significant functional and/or aesthetic morbidity and, until recently, platinum-based chemotherapy regimens have demonstrated antitumor activity without significant impact on the survival outcomes of patients [2]. Recent advances in the understanding of the Hedgehog (Hh) signaling pathway and its role in BCC pathogenesis, together with the discovery of pathway inhibitors, have led to the introduction of new treatment paradigms that may significantly improve clinical outcomes in this group of patients.

This article is based on previously conducted studies and does not contain human participants or animals performed by any of the authors. 


\section{METHODS}

\section{Search Strategy}

A PubMed search was performed using the following search terms: "locally advanced basal cell carcinoma," "metastatic basal cell carcinoma," "advanced basal cell carcinoma," and "hedgehog pathway inhibitors." Case reports, case series, cohort studies, and clinical trials were included in the initial screening of clinical studies. The first clinical study on Hedgehog Pathway Inhibitors (HPIs) was published in 2011; all clinical studies published after 2011 up to the present (November 2018) were considered in this review. The abstracts of all publications which appeared to be related to the topic were subsequently screened for relevance to the topic and articles assessed to be relevant were subsequently reviewed. Clinical case reports and case series with a follow-up duration of less than 6 months were excluded from the review.

\section{Inclusion Criteria}

Articles considered suitable to be included in the review were reviewed for the presence of a discussion on the following topics:

- Pathogenesis of BCC.

- Pharmacology (pharmacokinetics and pharmacodynamics) of HPIs.

- Clinical efficacy of HPIs in the setting of advanced BCC (i.e., locally advanced and metastatic BCC), including overall response rate, durability of response, predictors of response, and histological clearance of BCC.

- Emerging indications for HPIs, including neoadjuvant therapy, retreatment in cases of tumor progression, treatment of irresectable disease, and genetic syndromes (including basal cell nevus syndrome and xeroderma pigmentosum).

- Safety and adverse effects of HPIs, including potential risk of development of secondary squamous cell carcinoma, melanoma, and development of resistance to HPIs.

All articles which included a discussion on these topics were selected for inclusion in the review. A total of 41 clinical studies were identified and analyzed.

\section{THE HH PATHWAY AND ITS ROLE IN BCC PATHOGENESIS}

The skin contains different stem cell pools that contribute to the maintenance and repair of the various epidermal tissues, including the interfollicular epidermis, hair follicles, sebaceous glands, and sensory touch domes [3, 4]. The Hh pathway plays a critical role in the normal embryonic development of invertebrates and vertebrates, the development of its polarity, and organogenesis [5]. The Hh pathway is mainly dormant in the adult organism, but it may be activated during wound healing [6]. The pathway is involved in the maintenance of somatic stem cells and pluripotent cells important for tissue repair [7], including repair of the skin [8] and other organs [9-11].

Current evidence suggests that BCC arises from the basal keratinocytes of the interfollicular epidermis or the hair follicles [12, 13]. Abnormal activation of the Hh signaling pathway through various mechanisms has been observed in 95\% of sporadic BCCs [14]. Protein patched homolog 1 (PTCH) is a 12-pass transmembrane receptor protein that acts as a tumor suppressor and constitutionally suppresses the $\mathrm{Hh}$ signaling cascade. Hh ligands include the Sonic hedgehog (SHh), Indian hedgehog (IHh), and Desert hedgehog (DHh), all of which repress the functions of PTCH. In the normal physiological state, in which the Hh ligand is absent, PTCH blocks the migration of the transmembrane protein Smoothened (SMO) to the primary cilium of the cell, which in turn blocks downstream transcription of glioma-associated oncogene (GLI) transcription factors (GLI 1, GLI2, and GLI 3) (Fig. 1) [15]. Data from a number of studies show that $67 \%$ of BCCs exhibit loss of PTCH1 and 10\% have activating mutations of SMO [16-18], resulting in overexpression of GLI, which enters the cell nucleus and promotes cell division and tumorigenesis [19]. The incidence of metastatic disease is uncommon and is estimated to comprise $0.0028-0.55 \%$ of BCCs. Locally advanced 


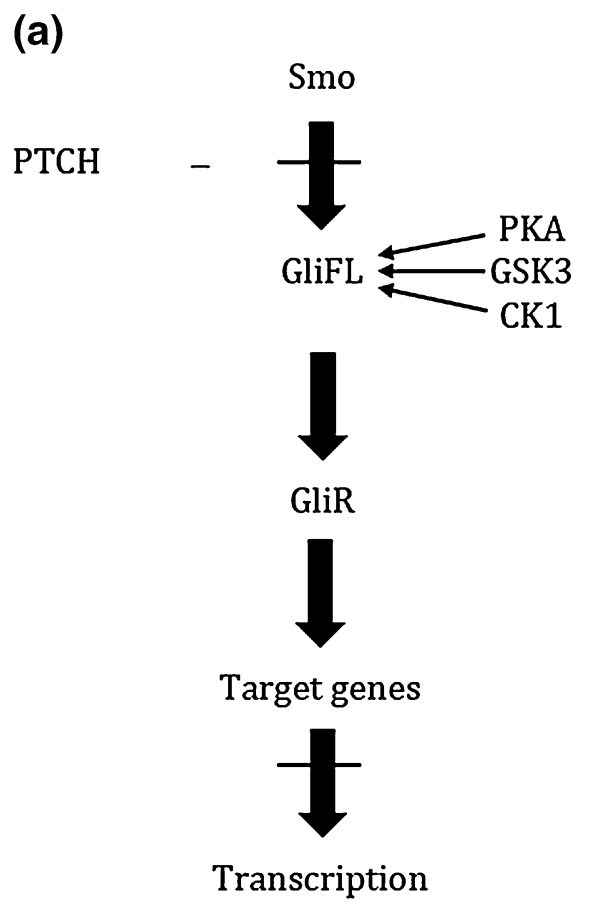

Fig. 1 A simplified representation of the Hedgehog $(\mathrm{Hh})$ signaling pathway and its role in basal cell carcinoma (BCC) pathogenesis. a In the absence of the Hh ligand, the full-length glioma-associated oncogene (GliFL) is phosphorylated by protein kinase A $(P K A)$, glycogen synthase kinase-3 (GSK 3), and casein kinase 1 (CKI). This results in cleavage of the full-length Gli into the Gli

disease is more difficult to characterize as to date no formal, widely accepted definition exists [1].

\section{DRUG DEVELOPMENT AND PHARMACOLOGY}

The first SMO antagonist to be discovered is a naturally occurring alkaloid, cyclopamine, that is found in the corn lily [20]. Cyclopamine binds SMO and inhibits activation of downstream Hh target genes that are essential for proper embryonic development [21]; it has been implicated in the occurrence of midline cyclops-appearing lambs born in the 1950s. Cyclopamine has suboptimal aqueous solubility and chemical stability, which limits its therapeutic usefulness [22]. Vismodegib is a small-
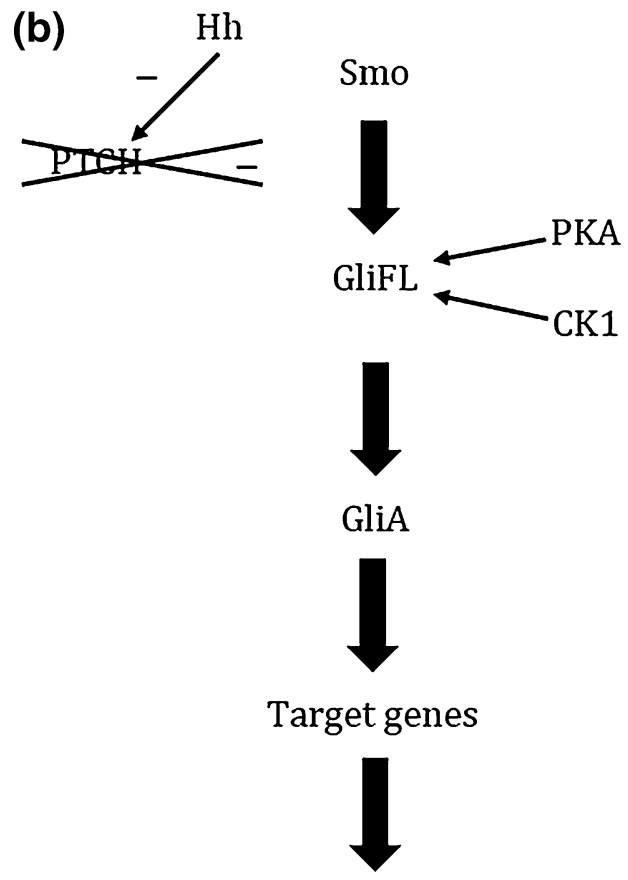

Transcription

repressor (GliR) that acts downstream to prevent transcription of the target genes. $\mathbf{b}$ In the presence of the $\mathrm{Hh}$ ligand, Smoothened (Smo) protein is phosphorylated by PKA and CK1, which leads to the formation of the Gli activator $(G l i A)$ and in turn to activation of downstream transcription. PTCH Protein patched homolog 1

molecule inhibitor of SMO that selectively inhibits the Hh signaling pathway by binding to the drug-binding pocket of SMO. The recommended dose is $150 \mathrm{mg}$ /day, based on maximal plasma concentration and pharmacodynamic response [23]. Sonidegib is a potent selective small-molecule antagonist that binds in the same drug-binding pocket of SMO. It has high tissue penetration and the ability to cross the blood-brain barrier with good oral bioavailability [24]. Sonidegib has a long terminal halflife of 29.6 days. The recommended dose is 200 $\mathrm{mg} /$ day [25].

HPIs act by inhibiting proliferation in BCC; they also induce the recruitment of cytotoxic $\mathrm{T}$ cells into the BCC and upregulate major histocompatibility (MHC) class I in BCC cells. These functions suggest the possibility of synergism when administered with immune modifiers 
[26]. Chemoresistance may occur between different SMO inhibitors; for example, patients who developed resistance to vismodegib may show diminished response to subsequent sonidegib therapy [27].

\section{CLINICAL DATA}

\section{Vismodegib}

A systematic review of eight studies on vismodegib involving 704 patients showed a weighted average overall response rate (ORR) of $62.1 \%$. All 704 patients received vismodegib at a dose of $150 \mathrm{mg} /$ day for a weighted median duration of 35.8 weeks in studies published between 2009 and 2015. Weighted average proportions of complete response (CR), partial response (PR), stable disease (SD), and progressive disease (PD) were 28.0, 34.1, 31.4, and $4.1 \%$, respectively [28]. Subgroup analysis revealed that the weighted $C R$ and $P R$ rates in locally advanced BCC (laBCC) was 31.1 and $33.6 \%$, respectively, and that the weighted $\mathrm{CR}$ and PR rates in metastatic BCC (mBCC) were 3.9 and $29.8 \%$, respectively [28].

A phase I study showed an ORR of $58 \%$ in 33 patients with advanced BCC (aBCC) who were receiving vismodegib [23, 29]. A follow-up, international, multicenter, phase II trial (ERIVANCE) was then conducted in 104 patients with aBCC [30] who were either assessed as inoperable laBCC cases or mBCC cases. The outcome measures are summarized in Tables 1 and 2. The ORR for mBCC and laBCC was 30 and $43 \%$, respectively. All patients with mBCC experienced PR (Table 1). Among those patients with laBCC, 22\% achieved PR and 21\% had CR (Table 2). The ORRs at the end of 12- and 30 months remained consistent with those reported in the primary analysis [31, 32]. Median odds survival (OS) for mBCC was 33.4 months [32], which is considerably higher than the OS of 8-24 months in the pre-vismodegib era $[33,34]$. However, only $7.7 \%$ remained on treatment, with the majority of discontinuations due to disease progression (27.9\%) [32].

The Expanded Access Study (EAS) was a USAbased, open-label, multicenter study conducted on patients with aBCC $(n=120)$ [35]. The ORR for laBCC and mBCC was $46.4 \%$ (Table 2) and $30.8 \%$ (Table 1), respectively. Median duration of exposure (DOE) was only 5.5 months as the study was terminated early by the sponsors after Federal Drug Administration (FDA) approval was obtained [35].

The Safety Events in Vismodegib (STEVIE) trial was another international, multi-center, open-label trial in patients with aBCC who received $150 \mathrm{mg} /$ day of vismodegib [36]. The results of interim analysis of 482 responseevaluable patients are shown in Tables 1 and 2 [36]. In the primary analysis of STEVIE [37], 1215 patients with a median follow-up duration and DOE of 17.9 months and 8.6 months, respectively, were evaluated. The ORR was 68.5 and $36.9 \%$ for patients with laBCC and mBCC, respectively. The median duration of response (DOR) and progression-free survival (PFS) was 22.7 and 22.1 months, respectively. Only $12 \%$ remained in the study, with adverse events being the main reason for treatment discontinuation.

Another study involving 31 laBCC cases showed that the proportion of patients with CR, $\mathrm{PR}, \mathrm{PD}$, and SD was 55, 42, 3, and 0\%, respectively [38]. In those with $\mathrm{PR}$, the mean reduction in tumor size was $52 \%$. Only two patients (8\%) discontinued treatment due to drug-related side effects [38]. However, the mean DOE was only 3 months [38].

\section{Predictors of Response}

Patients with laBCC [28], who were younger [32], were without prior systemic exposure to HPIs or chemotherapy [35], had Gorlin's syndrome [37], or had smaller tumors $(\leq 4 \mathrm{~cm})$ [32] have been reported to respond better to treatment. The efficacy of the treatment was comparable for aggressive and non-aggressive histological subtypes [32].

\section{Dosing}

Dosing of vismodegib at $150 \mathrm{mg} 3$ times per week failed to achieve levels associated with clinical efficacy [23]. However, in the STEVIE and ERIVANCE cohorts, treatment breaks of up to 8 weeks did not affect the efficacy of the 


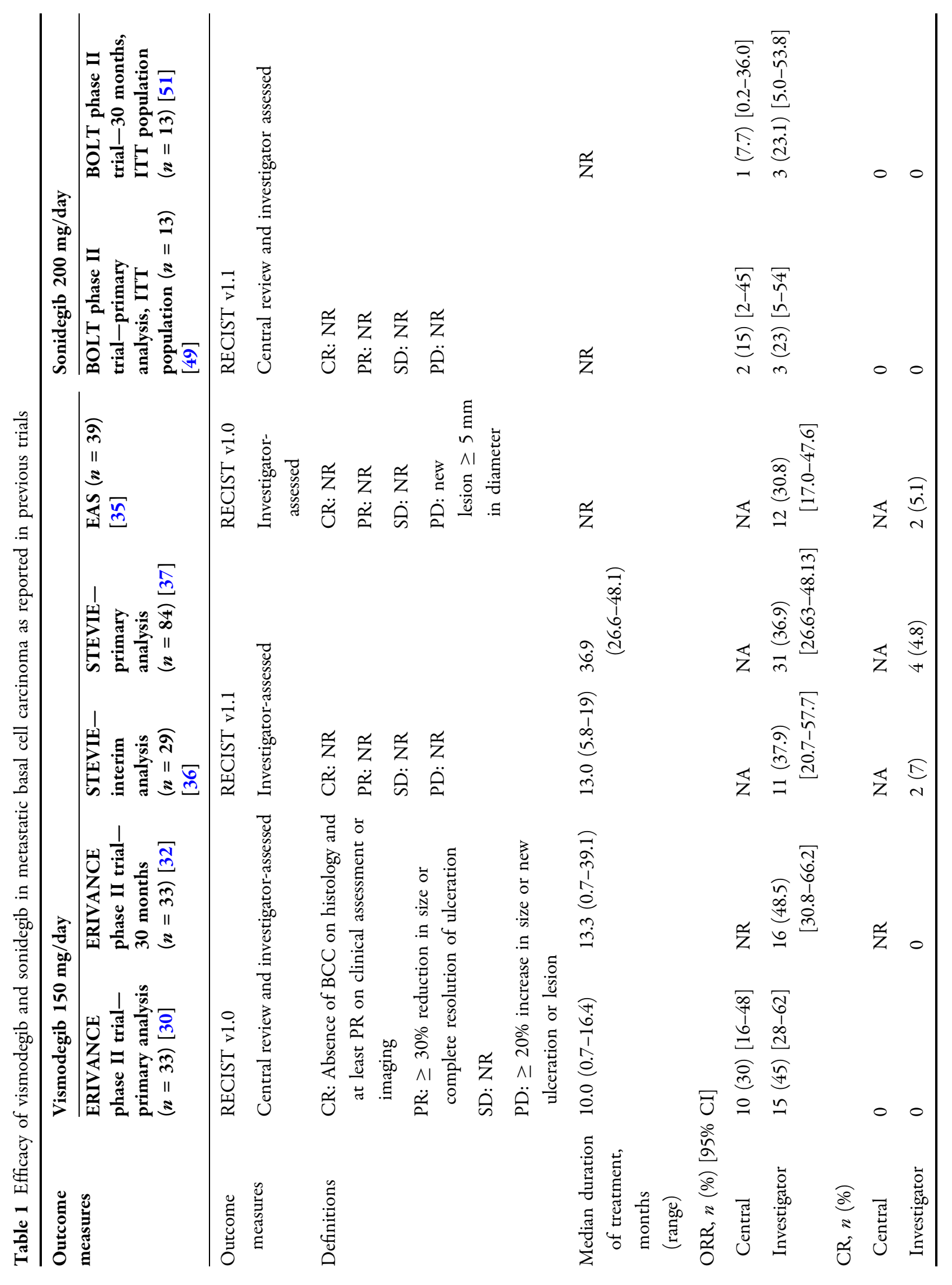




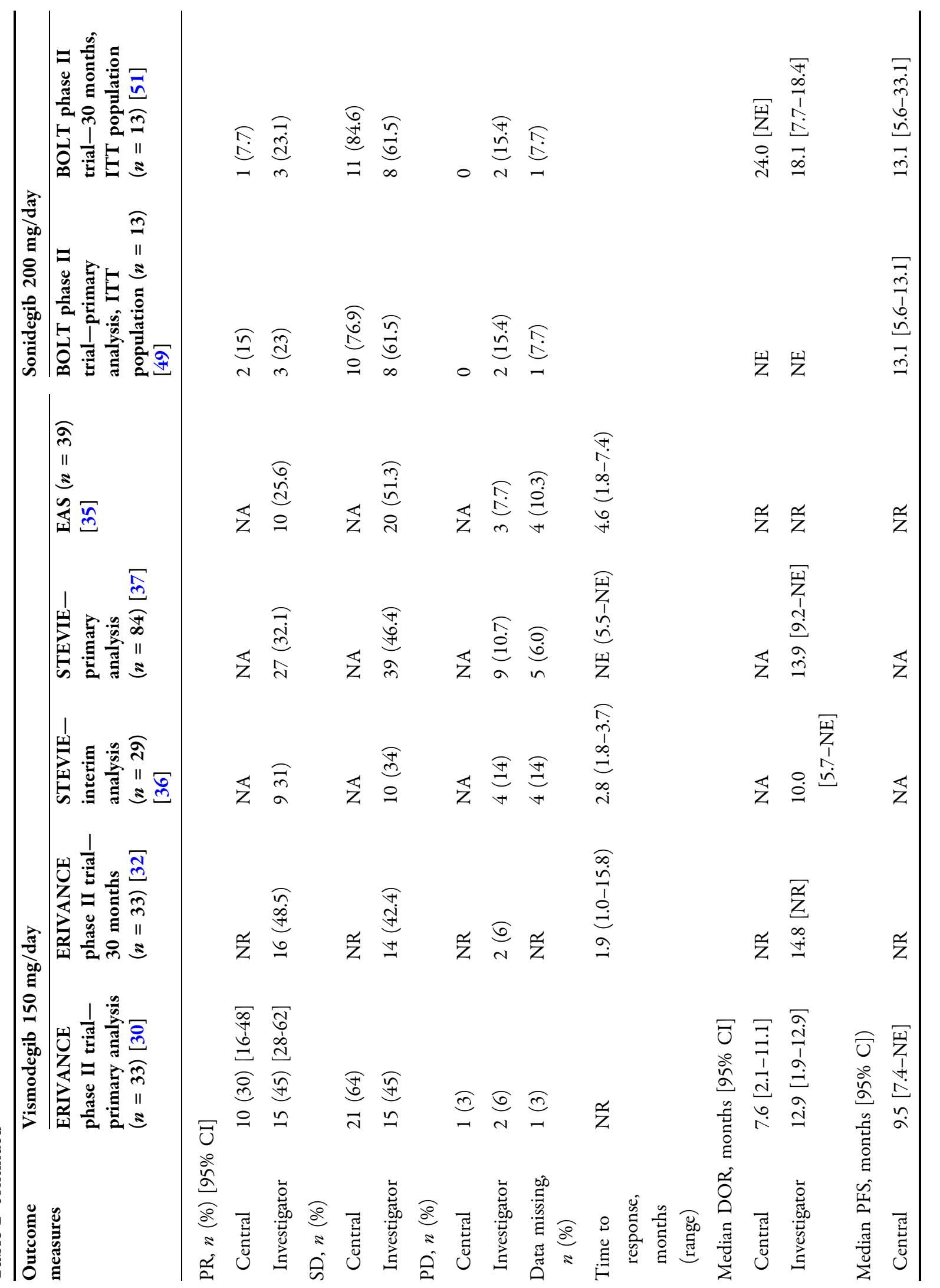




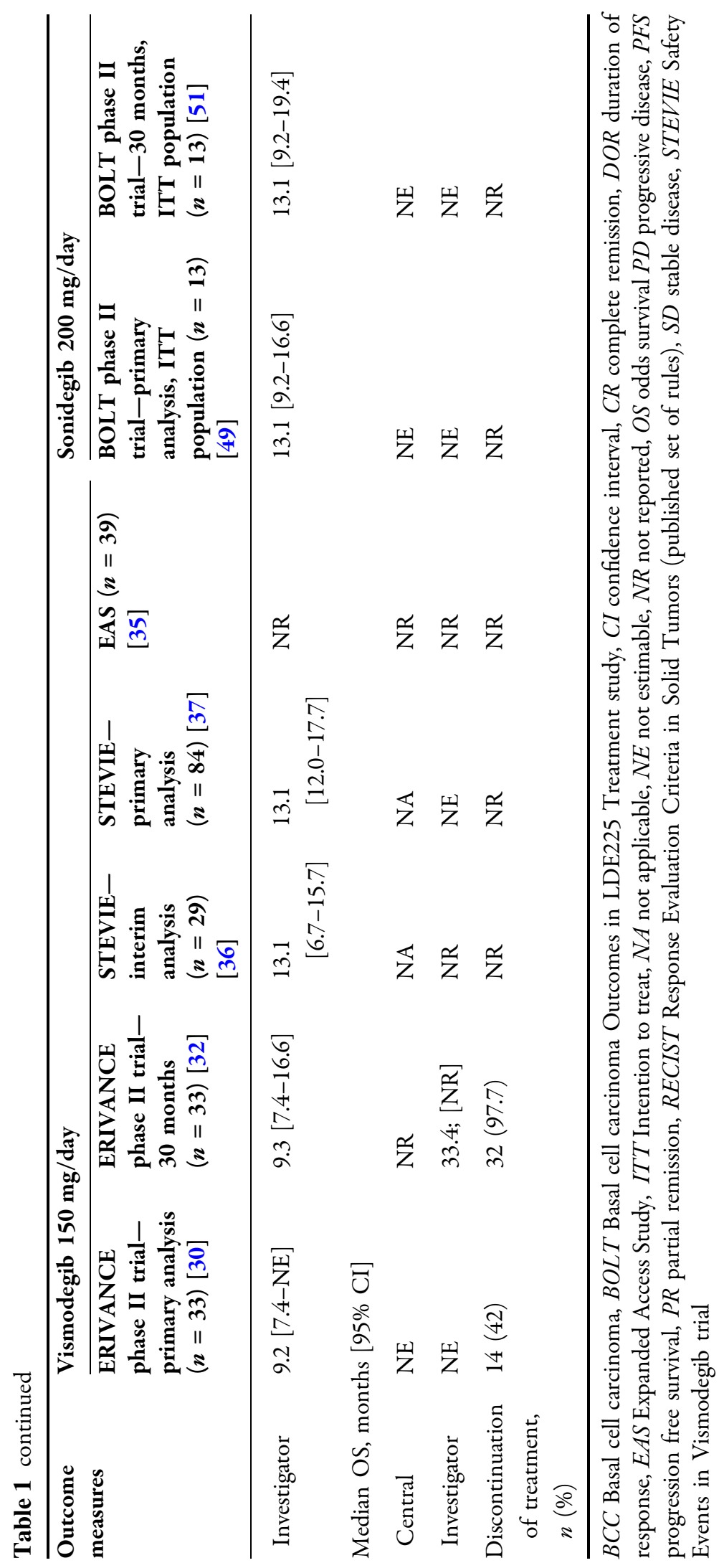




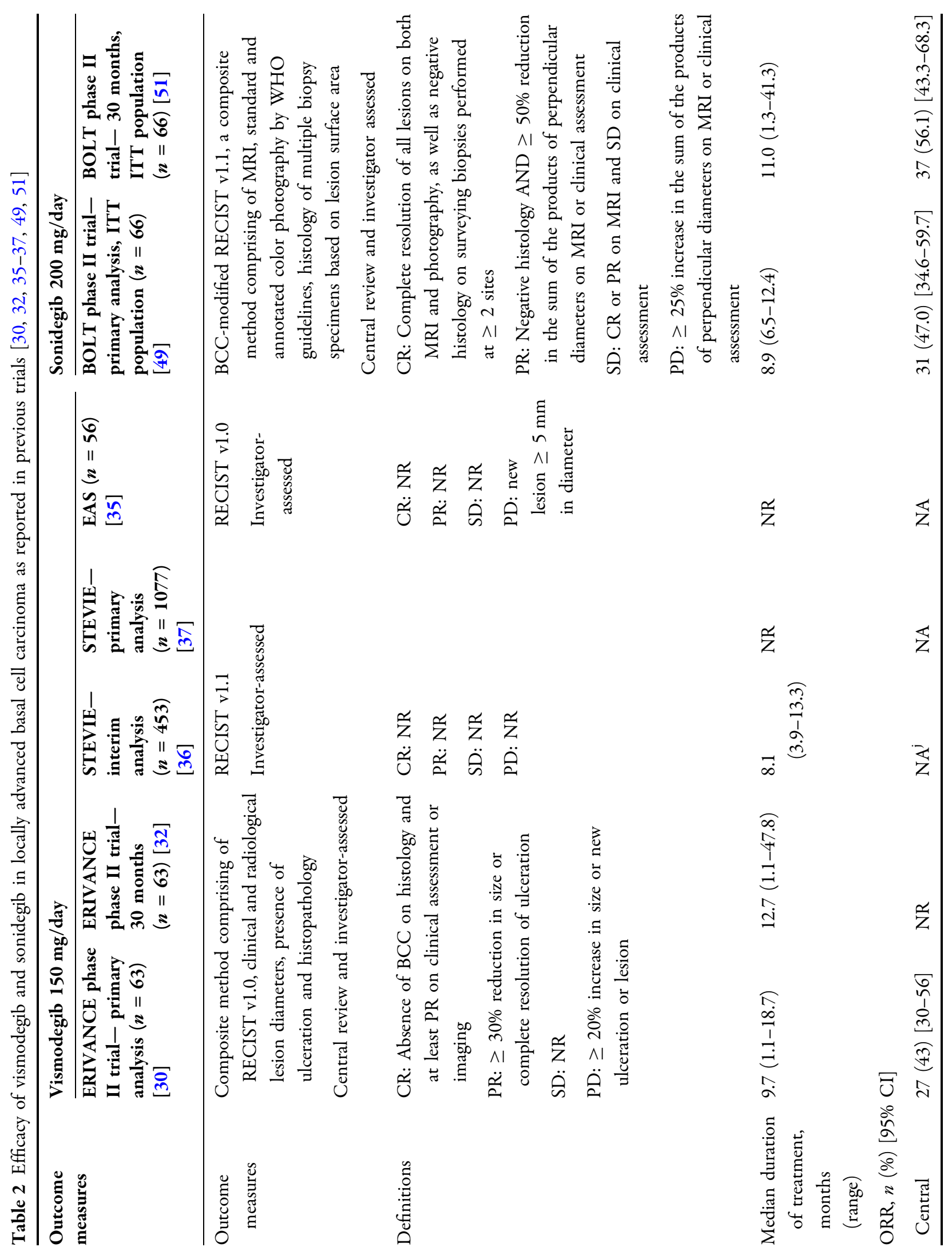




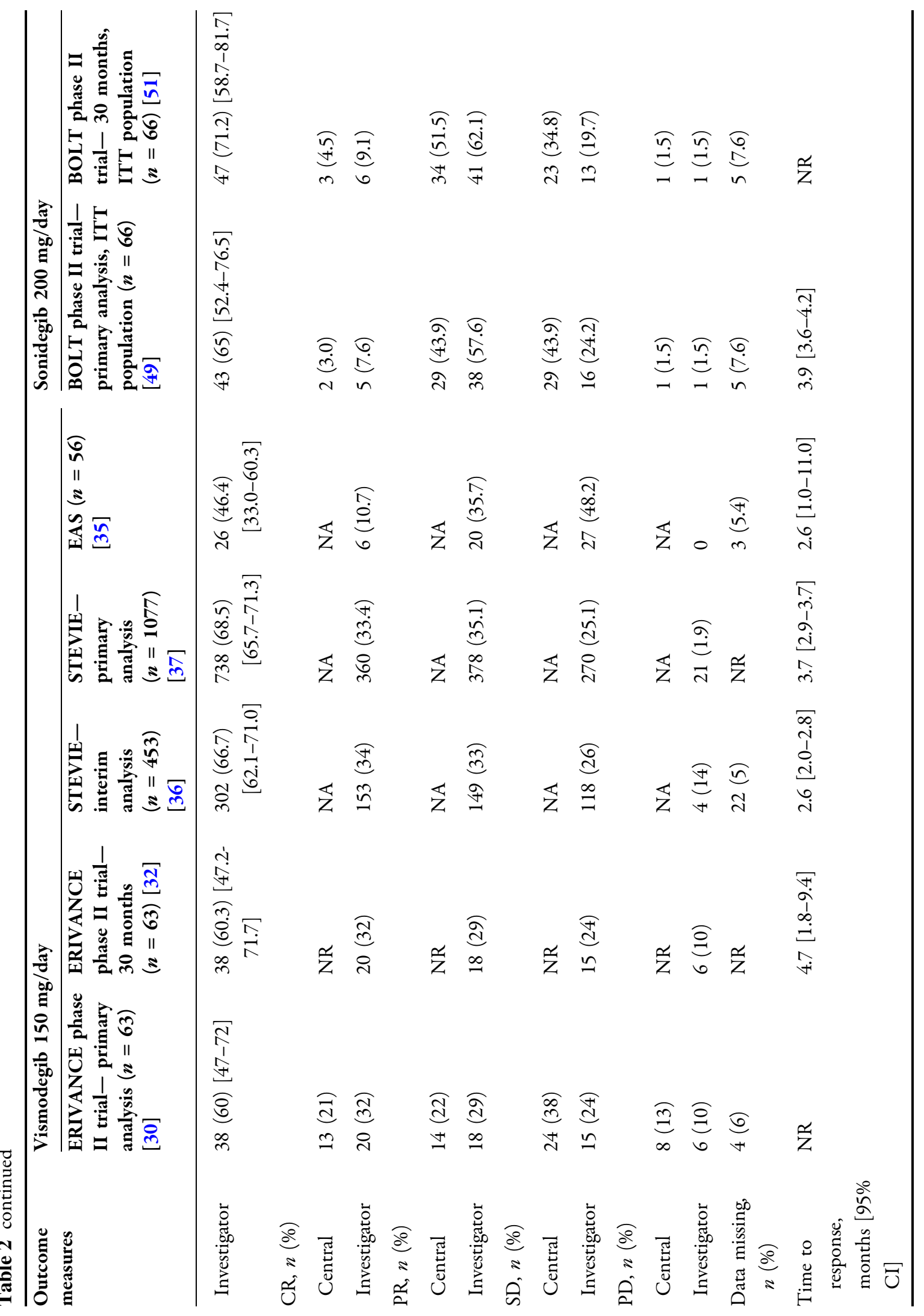




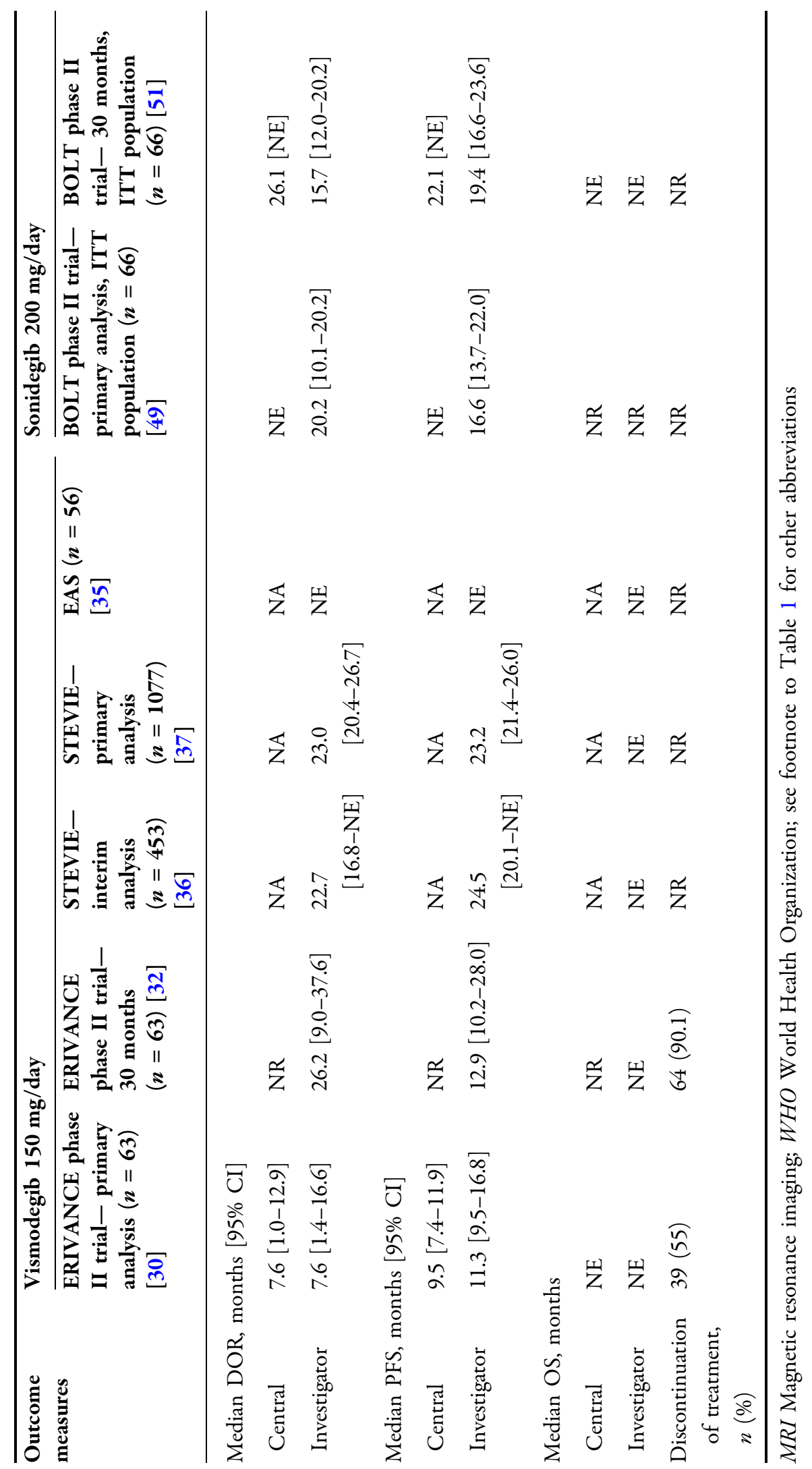


vismodegib treatment [32, 39]. Weekly interval dosing has been shown to ameliorate adverse effects and reduce drop-out while maintaining efficacy [40, 41]. However, concerns remain about the risk of tumor resistance with pulsed dosing [28].

\section{Durability of Response}

Although vismodegib has been shown to reduce tumor burden, treatment discontinuation leads to tumor regrowth. In one study, vismodegib suppressed tumor formation in animal models but did not eliminate aberrant clones harboring mutations [42]. The durability of response after drug discontinuation is unknown. Clinical remission was maintained for an average of 9.3 months in a study by Viscusi et al. [38] and was reported to be over 1 year in ERIVANCE [43]. In another study, after vismodegib discontinuation, the rate of development of new BCCs in Gorlin's syndrome remained low, but BCCs recurred at the same sites 5 months after drug cessation [44].

\section{Histological Clearance}

The rate of histological clearance has been reported to range from 16 to $44 \%$ [45]. Even in lesions that appeared to be clinically resolved, histological examination has revealed residual tumor in $17-43 \%$ of cases $[44,46]$.

\section{Sonidegib}

Sonidegib is available as an orally administered HPI or topical $0.75 \%$ cream for the treatment of laBCC and mBCC [47]. In one study, sonidegib $0.75 \%$ cream applied twice daily for 4 weeks led to clinical remission in $69 \%$ of BCCs, but the rate of histological clearance was $0 \%$ [48]. A phase I trial of orally administered sonidegib in patients with aBCCs revealed an ORR of $37.5 \%$ [25]. The follow-up Basal cell carcinoma Outcomes in LDE225 Treatment (BOLT) study is the only multicenter, randomized, double-blind, phase 2 trial to be conducted on the treatment of BCCs with HPIs [49] $(n=230)$. Patients were randomized to receive sonidegib $200 \mathrm{mg}$ /day $(n=79)$ and $800 \mathrm{mg} /$ day $(n=151)$. Outcome measures for mBCC and laBCC are shown in
Tables 1 and 2, respectively. Primary efficacy analysis performed at 6 months revealed an ORR of 36 and $34 \%$ in the $200 \mathrm{mg}$ group and $800 \mathrm{mg}$ group, respectively. Subgroup analysis of ORR according to laBCC and mBCC are shown in Tables 2 and 1, respectively. Neither the $200 \mathrm{mg}$ nor $800 \mathrm{mg}$ arm of the mBCC group met the targeted ORR of $>30 \%$ [50]. At 30 months, with a median follow-up duration of 38.2 months, ORRs for patients with laBCC and mBCC remained consistent. Median DOR and PFS for mBCC and laBCC are shown in Tables 1 and 2. respectively. For the patients with laBCC, estimated 2-year OS was $93.2 \%$ (200 mg) and 90.7\% (800 mg); for those with mBCC, the estimated 2-year OS was $69.3 \%$ $(200 \mathrm{mg}$ ) and $69.1 \%(800 \mathrm{mg})$. Of those patients initially enrolled in the trial, $93.0 \%$ discontinued treatment, mainly due to adverse events [51]. Based on early data, the clinical efficacy and patient survival of those given sonidegib $200 \mathrm{mg} /$ day and $800 \mathrm{mg} /$ day were approximately similar.

\section{Comparison of Sonidegib with Vismodegib}

There are no trials directly comparing sonidegib with vismodegib. However, comparisons between the various studies have been made. The CR rate of patients with laBCC to sonidegib in the BOLT study is comparable to that to vismodegib in the ERIVANCE study [51]. For laBCC, sonidegib demonstrated a better ORR than vismodegib. In an industry-sponsored analysis comparing the efficacy of vismodegib (ERIVANCE trial) and sonidegib (BOLT trial), sonidegib patients had a higher ORR, longer median PFS, and longer median DOR [52]. For patients with mBCC, the ORR for sonidegib was significantly lower than that for vismodegib.

\section{EMERGING INDICATIONS}

\section{Neoadjuvant Therapy}

Hedgehog pathway inhibitors are currently approved by the U.S. FDA for use as primary 
therapy for advanced BCC. More recently, studies have focused on the use of HPIs as neoadjuvant treatment prior to surgery, with the aim to reduce the extent of surgical treatment as well as increase the likelihood of curative resection. Ching et al. [53] presented a series of six patients with extensive laBCC in whom vismodegib was administered until there was either no further clinical response or patients stopped treatment due to adverse effects. Bone resection was avoided in three of these six patients, and clear margins achieved in four. Wong et al. [54] studied the use of vismodegib in 15 patients with locally advanced periocular and orbital BCC and reported 67\% CR, 20\% PR, and 13\% PD. The partial response noted in one patient permitted surgical resection with clear margins and orbital salvage in whom otherwise would have required an orbital exenteration.

\section{Retreatment in the Setting of Tumor Progression in Advanced BCC}

Alfieri et al. [55] studied six patients with aBCC who were previously part of the STEVIE trial. In all cases, the first vismodegib course was discontinued due to disease progression and patients underwent intercurrent therapies, which included radiotherapy, electrochemotherapy, chemotherapy, or surgery. Disease control (PR and SD) was achieved in $80 \%$ of patients following the second vismodegib course, and PR observed in 50\%.

\section{Irresectable Disease}

Yoon et al. [56] reported a case of regression of intracranial aBCC using sonidegib and itraconazole after disease progression 5 years following vismodegib treatment. The case report did not report outcome after 8 months following treatment.

\section{Combination Therapy}

Photodynamic therapy (PDT) is a well-established non-invasive treatment for BCC and commonly used in patients who are poor surgical candidates. Rizzo et al. [57] used the combination therapeutic regimen of red light PDT + vismodegib to treat patients with multiple nodular BCCs, treating 19 lesions in three patients, with the patients requiring between one and three sessions of PDT depending on lesion size. The results showed 90\% CR and 10\% PR, leading the authors to conclude that the combination therapy was well tolerated and yielded results superior to that of each individual therapy alone.

\section{Basal Cell Nevus Syndrome (Gorlin's Syndrome)}

Basal cell nevus syndrome is an autosomal dominant or spontaneous disorder that has complete penetrance and variable expressivity [58]. The principal causative mutation occurs on chromosome $9 \mathrm{q}(22.3-\mathrm{q} 31)$ and results in abnormalities of the PTCH1 gene. Because PTCH1 is an antagonist in the Hh signaling pathway, this mutation causes constitutional hyperactivity of the $\mathrm{Hh}$ pathway. Clinical manifestations include multiple BCCs (with presentation at an early age), odontogenic keratocysts of the maxilla and/or mandible, palmar or plantar pits, heterotopic calcification of the falx, bifid or missing ribs, wedged or fused vertebra, cardiac or ovarian fibromas, childhood medulloblastoma, and cleft lip and/or palate. The largest trial conducted to date involves a series of 41 patients treated with vismodegib [59]. The results of this trial show a mean reduced rate of new surgically-eligible BCCs compared with patients assigned to the placebo arm (2 vs. 34 lesions per patient/year). Subjects on continuous dosing regimens developed fewer surgically-eligible BCCs than did those with interrupted dosing (0.6 vs 1.7 per patient/ year). Only $17 \%$ of patients tolerated vismodegib continuously for the full 36 months.

\section{Xeroderma Pigmentosum}

Xeroderma Pigmentosum (XP) is an autosomal recessive disorder with a defective nucleotide excision repair pathway. It is characterized by photosensitivity and malignant tumor 
development due to cellular sensitivity to ultraviolet radiation. Patients with XP develop multiple skin malignancies at a young age and have a reduced life expectancy. Fife et al. [60] reported a case of XP in the nasal tip of an 8 -year-old child that was successfully treated with a $150 \mathrm{mg} /$ day, 5-month course of vismodegib without the need for surgery. The child remained in clinical remission for longer than 2 years.

\section{VISMODEGIB SAFETY AND ADVERSE EFFECTS}

In the ERIVANCE trial, treatment-emergent adverse events (TEAEs) with vismodegib included muscle spasms (71.2\%), alopecia (66.3\%), dysgeusia (55.8\%), weight loss $(51.9 \%)$, fatigue (43.3\%), and nausea (32.7\%). Patients who received treatment for $\geq 12$ months showed higher rates of TEAEs than did those receiving a shorter term of treatment, although the incidence of TEAEs assessed to be $\geq$ grade 3 was similar in both groups (56.3 and 55.4\%, respectively). Serious adverse events (SAEs) were reported in 36 of 104 patients (34.6\%) and these were considered to be related to vismodegib in 9 cases $(8.7 \%)$. There were four $(3.8 \%)$ patients with pneumonia and syncope each, three patients (2.9\%) each developed hip fracture and death, and two patients (1.9\%) each had cardiac failure, cellulitis, gastrointestinal hemorrhage, squamous cell carcinoma (SCC), pulmonary embolism, and deep vein thrombosis. Importantly, in many cases there were factors, including concurrent risk factors and medical comorbidities, which contributed to morbidity. There were no vismodegib-related deaths in the ERIVANCE trial [30]. A similar adverse effect profile was reported in an open-label, multicenter study of 119 patients with locally aBCC and $\mathrm{mBCC}$ who were assessed to be unsuitable for surgery or radiotherapy [35].

In the STEVIE trial, SAEs were reported in 108 patients $(22 \%)$, with nine patients $(2 \%)$ developing pneumonia, seven patients (1\%) experiencing general physical health deterioration, five patients (1\%) having SCC, and five patients (1\%) with dehydration. In 106 patients
(21\%) with grade 1 or 2 adverse events, 56 patients (11\%) with grade 3 adverse events, and 11 patients (2\%) with grade 4 adverse events, the adverse events led to the discontinuation of their vismodegib treatment [36]. The primary analysis of STEVIE demonstrated that vismodegib is tolerable in typical patients in clinical practice and that long-term exposure is not associated with worsening severity or frequency of TEAEs.

\section{Management of Adverse Effects}

Quinine provides relief to patients who experience muscle spasms. In 15 patients who received quinine for vismodegib-induced muscle spasms, two patients reported CR and 14 patients had PR [61]. It has been suggested that if quinine is ineffective, a treatment break of 2-4 weeks before restarting vismodegib may be helpful [61]. A trial of amlodipine $10 \mathrm{mg}$ daily for 2 weeks was shown to improve muscle cramps [62]. Other non-pharmacological methods include adequate fluid hydration and gentle exercise. Generalized or localized gradual alopecia can occur between 2.6 and 5.5 months of treatment, as shown in the ERIVANCE, STEVIE, and RegiSONIC trials. Conservative management with counseling and the use of a hair wig may be helpful [61]. Weight loss in patients on HPIs is likely to be multifactorial due to dysgeusia and loss of appetite. Strategies include food substitution or a dietitian review if patients experience a weight loss exceeding $5 \%$. In patients with progressive weight loss despite active intervention, treatment breaks and nutritional support until weight gain is achieved is advocated [61].

Diarrhoea and nausea was reported in approximately $20 \%$ of patients in clinical trials and is usually adequately treated with loperamide. Nausea can be alleviated with metoclopramide. Treatment breaks of up to 8 weeks' duration may be introduced to alleviate adverse effects, and these did not appear to compromise efficacy of treatment. This may be important in cases of Gorlin syndrome or advanced BCC to improve tolerability and compliance [61]. 


\section{Potential Risk of Development of Secondary SCC}

There are recent reports of patients who have developed SCC while on vismodegib treatment $[63,64]$. The hypothesis is that BCCs, under selection pressure form $\mathrm{Hh}$ inhibitors, activate the RTK/RAS/MAPK signaling pathway and thereby generate SCCs. This is a controversial topic. Bhutani et al. [65] performed a retrospective cohort study and showed that there was no increased risk of the development of SCC during vismodegib treatment.

\section{Potential Risks of Development of Melanoma}

There have been two reported cases of rapidly growing melanoma at between 8 and 9 months after discontinuation of vismodegib [66]. The total duration of the vismodegib treatment for both patients was 3 and 8 months, respectively. One of the patients developed the melanoma in close proximity to the primary BCC; however, it is uncertain if vismodegib played a contributory or protective role in the development of melanoma.

\section{Development of Resistance to HPIs}

Resistance to HPIs can be classified into primary and secondary resistance. Primary resistance has been postulated to bypass mechanisms of genes downstream of SMO, such as the $\mathrm{G} 497 \mathrm{~W}$ mutation [67]. Secondary resistance in patients who showed an initial response has been attributed to de novo mutations located on selected regions in the SMO to which HPIs bind or to selective clonal expansion of minority clones in the pre-treated tumor [68]. Some of the reported drug-binding mutations include D473, W281, Q477, C469, H231, and I408 [67-69]. Cross-resistance between HPIs has been reported; hence, switching between HPIs for patients who demonstrate resistance is not recommended. To a lesser extent, mutations in the suppressor of fused (SUFU) and gain-of-function mutations in Gli2 may also lead to vismodegibresistant tumors [68]. There is preliminary evidence that Gli antagonists and epidermal growth factor receptor inhibitors can be useful adjuncts in the treatment of HPI-resistant tumors [69].

\section{CONCLUSIONS}

Emerging data show that the novel class of HPIs, which includes vismodegib and sonidegib, are safe and effective treatment options for patients with laBCCs and mBCCs and for patients who are poor candidates for surgery or radiotherapy. Discontinuation of HPI treatment due to adverse events tends to be common, and these adverse events may be addressed either by supportive management or treatment breaks. Future studies are needed to elucidate the drivers of HPI resistance and how tumor resistance to HPIs may be overcome. It is clear from the current data that HPIs will significantly alter the treatment landscape of BCCs at the present time and in the future.

\section{ACKNOWLEDGEMENTS}

Funding. No funding or sponsorship was received for this study or publication of this article.

Authorship. All named authors meet the International Committee of Medical Journal Editors (ICMJE) criteria for authorship for this article, take responsibility for the integrity of the work as a whole, and have given their approval for this version to be published.

Disclosures. Evelyn Yu-Xin Tay, Yee-Leng Teoh, and Matthew Sze-Wei Yeo have nothing to disclose.

Compliance with Ethics Guidelines. This article is based on previously conducted studies and does not contain human participants or animals performed by any of the authors. 
Open Access. This article is distributed under the terms of the Creative Commons Attribution-NonCommercial 4.0 International License (http://creativecommons.org/licenses/ by-nc/4.0/), which permits any noncommercial use, distribution, and reproduction in any medium, provided you give appropriate credit to the original author(s) and the source, provide a link to the Creative Commons license, and indicate if changes were made.

\section{REFERENCES}

1. Rogers H, Weinstock M, Feldman S, Coldiron B. Incidence estimate of nonmelanoma skin cancer (keratinocyte carcinomas) in the US population, 2012. JAMA Dermatol. 2015;151(10):1081-6.

2. Pfeiffer P, Hansen O, Rose C. Systemic cytotoxic therapy of basal cell carcinoma: a review of the literature. Eur J Cancer. 1990;26(1):73-7.

3. Fuchs E. Scratching the surface of skin development. Nature. 2007;445(7130):834-42.

4. Blanpain C, Fuchs E. Epidermal homeostasis: a balancing act of stem cells in the skin. Nat Rev Mol Cell Biol. 2009;10(3):207-17.

5. Varjosalo M, Taipale J. Hedgehog: functions and mechanisms. Genes Dev. 2008;22(18):2454-72.

6. Le H, Kleinerman R, Lerman OZ, et al. Hedgehog signalling is essential for normal wound healing. Wound Repair Regen. 2008;16(6):768-73.

7. Lowry WE, Richter L, Yachechko R, et al. Generation of human induced pluripotent stem cells form dermal fibroblasts. Proc Natl Acad Sci USA. 2008;105(8):2883-8.

8. Zhou JX, Jia LW, Liu WM, et al. Role of sonic hedgehog in maintaining a pool of proliferating stem cells in the human fetal epidermis. Hum Reprod. 2006;21(7):1698-704.

9. Lewis MT, Veltmaat JM. Next stop, the twilight zone: Hedgehog network regulation of mammary gland development. J Mammary Gland Biol Neoplasia. 2004;9(2):165-81.

10. Stecca B, Mas C, Clement V, et al. Melanomas require HEDGEHOG-GLI signaling regulated by interactions between GLI1 and the RAS-MEK/AKT pathways. Proc Natl Acad Sci USA. 2007;104(14):5895-900.
11. Watkins DN, Berman DM, Burkholder SG, Wang B, Beachy PA, Baylin SB. Hedgehog signalling within airway epithelial progenitors and in small-cell lung cancer. Nature. 2003;422(6929):313-7.

12. Youssef KK, van Keymeulen A, Lapouge G, et al. Identification of the cell lineage at the origin of basal cell carcinoma. Nat Cell Biol. 2010;12(3):299-305.

13. Wang GY, Wang J, Mancianti ML, Epstein EH Jr. Basal cell carcinomas arise from hair follicle stem cells in $\operatorname{Ptch} 1( \pm)$ mice. Cancer Cell. 2011;19(1):114-24.

14. Epstein EH. Basal cell carcinomas: attack of the hedgehog. Nat Rev Cancer. 2008;8(10):743-54.

15. Bakshi A, Chaudhary SC, Rana M, Elmets CA, Athar M. Basal cell carcinoma pathogenesis and therapy involving hedgehog signalling and beyond. Mol Carcinogenesis. 2017;56(12):2543-57.

16. Xie J, Murone M, Luoh SM, et al. Activating Smoothened mutations in sporadic basal-cell carcinoma. Nature. 1998;391(6662):90-2.

17. Reifenberger J, Wolter M, Knobbe CB, et al. Somatic mutations in the PTCH, SMOH, SUFUH and TP53 genes in sporadic basal cell carcinomas. Br J Dermatol. 2005;152(1):43-51.

18. Khavari PA. Modelling cancer in human skin tissue. Nat Rev Cancer. 2006;6(4):270-80.

19. Aszterbaum M, Rothman A, Johnson R, et al. Identification of mutations in the human PATCHED gene in sporadic basal cell carcinomas and in patients with the basal cell nevus syndrome. J Invest Dermatol. 1998;110(6):885-8.

20. Cooper M, Porter J, Young K, Beachy PA. Teratogenmediated inhibition of target tissue response to SHH signaling. Science. 1998;280(5369):1603-7.

21. Incardona JP, Gaffield W, Kapur RP, Roelink H. The teratogenic Veratrum alkaloid cyclopamine inhibits sonic hedgehog signal transduction. Development. 1998;125(18):3553-62.

22. Winkler JD, Isaacs A, Holderbaum L, Tatard V, Dahmane N. Design and synthesis of inhibitors of Hedgehog signalling based on the alkaloid cyclopamine. Org Lett. 2009;11(13):2824-7.

23. Lorusso PM, Rudin CM, Reddy JC, et al. Phase I trial of hedgehog pathway inhibitor vismodegib (GDC0449) in patients with refractory, locally advanced or metastatic solid tumors. Clin Cancer Res. 2011;17(8):2502-11. 
24. Pan S, Wu X, Jiang J, et al. Discovery of NVPLDE225, a potent and selective smoothened antagonist. ACS Med Chem Lett. 2010;1(3):130-4.

25. Rodon J, Tawbi HA, Thomas AL, et al. A phase I, multicenter, open-label, first-in-human, dose escalation study of the oral smoothened inhibitor Sonidegib (LDE225) in patients with advanced solid tumors. Clin Cancer Res. 2014;20(7):1900-9.

26. Otsuka A, Dreier J, Cheng PF, et al. Hedgehog pathway inhibitors promote adaptive immune responses in basal cell carcinoma. Clin Cancer Res. 2015;21(6):1289-97.

27. Danial C, Sarin KY, Oro AE, Chang AL. An investigator-initiated open-label trial of sonidegib in advanced basal cell carcinoma patients resistant to vismodegib. Clin Cancer Res. 2016;22(6):1325-9.

28. Jacobsen AA, Aldahan AS, Hughes OB, Shah VV, Strasswimmer J. Hedgehog Pathway Inhibitor therapy for locally advanced and metastatic basal cell carcinoma: a systematic review and pooled analysis of interventional studies. JAMA Dermatol. 2016;152(7):816-24.

29. Von Hoff DD, LoRusso PM, Rudin CM, et al. Inhibition of the Hedgehog pathway in advanced basalcell carcinoma. N Engl J Med. 2009;361(12):1164-72.

30. Sekulic A, Migden MR, Oro AE, et al. Efficacy and safety of Vismodegib in advanced basal-cell carcinoma. N Engl J Med. 2012;366(23):2171-9.

31. Sekulic A, Migden MR, Lewis K, et al. Pivotal ERIVANCE basal cell carcinoma (BCC) study: 12-month update of efficacy and safety of Vismodegib in advanced BCC. J Am Acad Dermatol. 2015;72(6):1021-6.

32. Sekulic A, Midgen MR, Basset-Seguin N, et al. Longterm safety and efficacy of vismodegib in patients with advanced BCC: final update of the pivotal ERIVANCE BCC study. BMC Cancer. 2017;17(1):332.

33. Von Domarus H, Stevens PJ. Metastatic basal cell carcinoma Report of five cases and review of 170 cases in the literature. J Am Acad Dermatol. 1984;10(6):1043-60.

34. McCusker M, Basset-Seguin N, Dummer R, et al. Metastatic basal cell carcinoma: prognosis dependent on anatomic site and spread of disease. Eur J Cancer. 2014;50(4):774-83.

35. Chang AL, Solomon JA, Hainsworth JD, et al. Expanded access study of patients with advanced basal cell carcinoma treated with Hedgehog pathway inhibitor, vismodegib. J Am Acad Dermatol. $2014 ; 70(1): 60-9$.

36. Basset-Seguin N, Hauschild A, Grob JJ, et al. Vismodegib in patients with advanced basal cell carcinoma (STEVIE): a pre-planned interim analysis of an international, open-label trial. Lancet Oncol. 2015;16(6):729-36.

37. Seguin-Basset N, Hauschild A, Kunstfeld R, et al. Vismodegib in patients with advanced basal cell carcinoma: primary analysis of STEVIE, an international, open-label trial. Eur J Cancer. 2017;86:334-48.

38. Viscusi KS, Hanke CW. Vismodegib for locally advanced basal cell carcinoma: descriptive analysis of a case series and comparison to the literature. J Drugs Dermatol. 2015;14(9):956-62.

39. Hanke CW, Mhatre SK, Oliveri D, et al. Vismodegib use in clinical practice: analysis of a United States medical claims database. J Drugs Dermatol. 2018;17(2):143-8.

40. Becker LR, Aakhus AE, Reich HC, et al. A novel alternate dosing of Vismodegib for treatment of patients with advanced basal cell carcinomas. JAMA Dermatol. 2017;153(4):321-2.

41. Dreno B, Kunstfeld R, Hauschild A, et al. Two intermittent vismodegib dosing regimens in patients with multiple basal-cell carcinomas (MIKIE): a randomized, regimen-controlled, double-blind, phase 2 trial. Lancet Oncol. 2017;18(3):404-12.

42. Hutchin ME, Kariapper MS, Grachtchouk M, et al. Sustained hedgehog signaling is required for basal cell carcinoma proliferation and survival: conditional skin tumorigenesis recapitulates the hair growth cycle. Genes Dev. 2005;19(2):214-23.

43. Dessinioti C, Plaka M, Stratigos AJ. Vismodegib for the treatment of basal cell carcinoma: results and implications of the ERIVANCE BCC trial. Future Oncol. 2014;10(6):927-36.

44. Tang JY, Mackay-Wiggan JM, Aszterbaum M, et al. Inhibiting the hedgehog pathway in patients with the basal-cell nevus syndrome. $\mathrm{N}$ Engl J Med. 2012;366(23):2180-8.

45. Sofen H, Gross KG, Goldberg LH, et al. A phase II, multicenter, open-label, 3-cohort trial evaluating the efficacy and safety of vismodegib in operable basal cell carcinoma. J Am Acad Dermatol. 2015;73(1):99-105.

46. Ally MS, Asai S, Wysong A, et al. An investigatorinitiated open-label clinical trial of vismodegib as a 
neoadjuvant to surgery for high-risk basal cell carcinoma. J Am Acad Dermatol. 2014;71(5):904-11.

47. Collier NJ, Ali FR, Lear JT. The safety and efficacy of sonidegib for the treatment of locally advanced basal cell carcinoma. Exp Rev Anticancer Ther. 2016;16(10):1011-8.

48. Skvara H, Kalthoff F, Meingassner JG, et al. Topical treatment of basal cell carcinomas in nevoid basal cell carcinoma syndrome with a Smoothened inhibitor. J Invest Dermatol. 2011;131(8):1735-44.

49. Migden MR, Guminski A, Gutzmer R, et al. Treatment with two different doses of sonidegib in patients with locally advanced or metastatic basal cell carcinoma (BOLT): a multicenter, randomised, double-blind phase 2 trial. Lancet Oncol. 2015;16(6):716-28.

50. Casey D, Demko S, Shord S, et al. FDA approval summary: sonidegib for locally advanced basal cell carcinoma. Clin Cancer Res. 2017;23(10):2377-81.

51. Lear JT, Migden MR, Lewis KD, et al. Long-term efficacy and safety of sonidegib in patients with locally advanced and metastatic basal cell carcinoma: 30-month analysis of the randomized phase 2 BOLT study. J Eur Acad Dermatol Venereol. 2018;32(3):372-81.

52. Odom D, Mladsi D, Purser M, et al. A matchingadjusted indirect comparison of sonidegib and vismodegib in advanced basal cell carcinoma. J Skin Cancer. 2017;2017:6121760.

53. Ching JA, Curtis HL, Braue JA, et al. The impact of neoadjuvant hedgehog inhibitor therapy on the surgical treatment of extensive basal cell carcinoma. Ann Plast Surg. 2015;74[Suppl 4]:S193-7.

54. Wong KY, Fife K, Lear JT, Price RD, Durrani A. Vismodegib for locally advanced periocular and orbital basal cell carcinoma: a review of 15 consecutive cases. Plast Reconstr Surg Glob Open. 2017;5(7):e1424.

55. Alfieri S, Bergamini C, Granata R, Locati L, Licitra L, Bossi P. Retreatment with vismodegib after progression in advanced basal cell carcinoma: first-time report of a single-institution experience. Targeted Oncol. 2018;13(2):253-6.

56. Yoon J, Apicelli AJ, Pavlopoulos TV. Intracranial regression of an advanced basal cell carcinoma using sonidegib and itraconazole after failure with vismodegib. JAAD Case Reports. 2018;4(1):10-2.

57. Rizzo JM, Segal RJ, Zeitouni NC. Combination vismodegib and photodynamic therapy for multiple basal cell carcinomas. Photodiagnosis Photody Ther. 2018;21:58-62.
58. Akbari M, Chen H, Guo G, Legan Z, Ghali G. Basal cell nevus syndrome (Gorlin syndrome): genetic insights, diagnostic challenges, and unmet milestones. Pathophysiology. 2018;25(2):77-82.

59. Tang JY, Ally MS, Chanana AM, et al. Inhibition of the hedgehog pathway in patients with basal-cell nevus syndrome: final results from the multicenter, randomised, double-blind, placebo-controlled, phase 2 trial. Lancet Oncol. 2016;17(12):1720-31.

60. Fife D, Laitinen MA, Myers DJ, Landsteiner PB. Vismodegib therapy for basal cell carcinoma in an 8 -year-old Chinese boy with xeroderma pigmentosum. Pediatric Dermatol. 2017;34(2):163-5.

61. Fife $\mathrm{K}$, Herd R, Lalondrelle $\mathrm{S}$, et al. Managing adverse events associated with vismodegib in the treatment of basal cell carcinoma. Future Oncol. 2017;13(2):175-84.

62. Ally MS, Tang JY, Lindgren J, et al. Effect of calcium channel blockade on vismodegib-induced muscle cramps. JAMA Dermatol. 2015;151(10):1132-4.

63. Feigenbaum L, Scott BL, Moye MS, Nijhawan RI. Development of basal cell carcinoma with squamous differentiation during Vismodegib treatment. Dermatol Surg. 2017;43(7):989-91.

64. Mohan SV, Chang J, Li S, Henry AS, Wood DJ, Chang AL. Increased risk of cutaneous squamous cell carcinoma after vismodegib therapy for basal cell carcinoma. JAMA Dermatol. 2016;152(5):527-32.

65. Bhutani T, Abrouk M, Sima CS, et al. Risk of cutaneous squamous cell carcinoma after treatment of basal cell carcinoma with vismodegib. J Am Acad Dermatol. 2017;77(4):713-8.

66. Giuffrida R, Kashofer K, Dika E. Fast growing melanoma following treatment with vismodegib for locally advanced basal cell carcinoma: report of two cases. Eur J Cancer. 2018;91:177-9.

67. Pricl S, Cortelazzi B, Dal Col V, et al. Smoothened (SMO) receptor mutations dictate resistance to vismodegib in basal cell carcinoma. Mol Oncol. 2015;9(2):389-97.

68. Sharpe HJ, Pau G, Dijkgraaf GJ, et al. Genomic analysis of Smoothened inhibitor resistance in basal cell carcinoma. Cancer Cell. 2015;27(3):327-41.

69. Atwood SX, Sarin KY, Whitson RJ, et al. Smoothened variants explain the majority of drug resistance in basal cell carcinoma. Cancer Cell. 2015;27(3):342-53. 